\title{
Analysis of Fraxinus pollen seasons in selected cities of Poland in 2018
}

\author{
Krystyna Piotrowska-Weryszko', Elżbieta Weryszko-Chmielewska', Agata Konarska', Aneta Sulborska', \\ Beata Żuraw' ${ }^{1}$, Małgorzata Puc ${ }^{2}$, Daniel Kotrych ${ }^{3}$, Alina Stacewicz², Ewa M. Świebocka', Adam Rapiejko ${ }^{5,6}$, \\ Małgorzata Malkiewicz ${ }^{7}$, Ewa Kalinowska ${ }^{5}$, Katarzyna Dąbrowska-Zapart ${ }^{8}$, Kazimiera Chłopek, \\ Monika Ziemianin', Agnieszka Lipiec ${ }^{10}$, Artur Górecki" ${ }^{11}$, Dariusz Jurkiewicz"12, \\ Agnieszka Świdnicka-Siergiejko ${ }^{13}$, Kornel Szczygielski ${ }^{12}$, Agnieszka Kwaśnik-Balińnska ${ }^{12}$, Grzegorz Siergiejk0 ${ }^{4}$, \\ Piotr Rapiejko ${ }^{5,12}$ \\ ${ }^{1}$ Department of Botany, University of Life Sciences in Lublin, Poland \\ ${ }^{2}$ Department of Botany and Nature Conservation, Faculty of Biology, University of Szczecin, Poland \\ ${ }^{3}$ Department of Orthopedics and Traumatology, Pomeranian Medical University of Szczecin, Poland \\ ${ }^{4}$ Pediatrics, Gastroenterology and Allergology Department, University Children Hospital, Medical University \\ of Bialystok, Poland \\ ${ }^{5}$ Allergen Research Center, Poland \\ ${ }^{6}$ Oxford Archaeology Ltd., Oxford, England \\ ${ }^{7}$ Department of Palaeobotany, Institute of Geological Sciences, University of Wroclaw, Poland \\ ${ }^{8}$ Department of Paleontology and Stratigraphy, Faculty of Earth Sciences, University of Silesia, Poland \\ ${ }^{9}$ Department of Clinical and Environmental Allergology, Jagiellonian University, Medical College, Poland \\ ${ }^{10}$ Department of Prevention of Environmental Hazards and Allergology, Medical University of Warsaw, Poland \\ ${ }^{11}$ Institute of Botany, Jagiellonian University, Poland \\ ${ }^{12}$ Department of Otolaryngology with Division of Cranio-Maxillo-Facial Surgery in Military Institute of Medicine, \\ Warsaw, Poland \\ ${ }^{13}$ Department of Gastroenterology and Internal Medicine, Medical University of Bialystok, Poland
}

Abstract: The study compares the ash pollen seasons in Szczecin, Drawsko Pomorskie, Bydgoszcz, Zielona Gora, Wroclaw, Opole, Sosnowiec, Cracow, Piotrkow Trybunalski, Warsaw, Lublin, Olsztyn and Bialystok in 2018. The investigations were carried out using the volumetric method. The ash pollen season began between April $7^{\text {th }}$ and April $10^{\text {th }}$. Maximum daily pollen concentrations were noted earliest on April $10^{\text {th }}$ and latest on April $17^{\text {th }}$. The greatest risk of allergies caused by the presence of airborne ash pollen was observed in Lublin.

Key words: aeroallergens, pollen concentration, ash (Fraxinus), 2018

$\mathrm{T}$ he European ash (Fraxinus excelsior) from the family Oleaceae is the only species of the genus Fraxinus growing in Poland in natural stands. Due to its fast growth, this tree is frequently used in urban plantings as well as it is planted along roads, in parks, and around buildings. Over a dozen other species belonging to the genus Fraxinus are used for cultivation, e.g. green ash (Fraxinus pennsylvanica) and manna ash (Fraxinus ornus) [1].
According to many authors, allergens contained in the pollen of Fraxinus are one of the causes of pollen allergy during the spring period [2-5]. It has been found that cross reactions occur between allergens of the pollen of Betula and Fraxinus as well as between allergens of the pollen of ash and other plants of the family Oleaceae (olive, privet) $[6,7]$. The timing of pollen shed of ash and strongly allergenic birch coincides, which may promote enhanced allergy symptoms [8]. 
Aim

The aim of the study was to compare the Fraxinus pollen concentrations in the air of 13 selected cities in Poland in 2018.

\section{Material and method}

Measurements of airborne pollen of Fraxinus were performed in Szczecin, Drawsko Pomorskie, Bydgoszcz, Zielona Gora, Wroclaw, Opole, Sosnowiec, Cracow, Piotrkow Trybunalski, Warsaw, Lublin, Olsztyn and Bialystok. Aeroplankton samples were carried out with the volumetric method using Burkard or Lanzoni pollen samplers. Pollen concentrations were expressed as the number of pollen grains in $1 \mathrm{~m}^{3}$ of air per day $\left(\mathrm{P} / \mathrm{m}^{3}\right)$. The duration of the ash pollen season was determined with the $95 \%$ method. The start and end of the season were defined as the date when $2.5 \%$ and $97.5 \%$ of the seasonal cumulative pollen count was trapped, respectively. Number of days with concentration above threshold was counted. The threshold values were determined on the basis of literature data $[7,9]$.

\section{Results and discussion}

In 2018 in most of the cities studied, the ash pollen season started later and lasted shorter than in 2017 [9]. At all of the study sites, in 2018 the start of the ash pollen season occurred at the similar date, between April $7^{\text {th }}$ and April $10^{\text {th }}$ (tab. 1). The end of the ash pollen season was recorded earliest on April $17^{\text {th }}$ (Cracow) and latest on April 25 $5^{\text {th }}$ (Bialystok, Wroclaw) (fig. 1-6).

The highest daily ash pollen concentration was recorded in Cracow $\left(829 \mathrm{P} / \mathrm{m}^{3}\right)$, followed by Lublin $\left(638 \mathrm{P} / \mathrm{m}^{3}\right)$, whereas the lowest peak value occurred in Wroclaw $\left(106 \mathrm{P} / \mathrm{m}^{3}\right)$ and Bialystok $\left(109 \mathrm{P} / \mathrm{m}^{3}\right)$. These values were higher than in the previous years $[9,10]$.

Table 1. Characteristics of Fraxinus pollen season in 2018.

\begin{tabular}{|c|c|c|c|c|c|}
\hline \multirow{2}{*}{ Site } & \multirow{2}{*}{$\begin{array}{c}\text { Duration of pollen } \\
\text { season }\end{array}$} & \multirow{2}{*}{$\begin{array}{l}\text { Peak value }\left[\mathrm{P} / \mathrm{m}^{3}\right] \\
\text { and peak date }\end{array}$} & \multicolumn{2}{|c|}{ Number of days with concentration above threshold } & \multirow{2}{*}{$\begin{array}{l}\text { Annual pollen } \\
\text { sum }\end{array}$} \\
\hline & & & $45 \mathrm{P} / \mathrm{m}^{3}$ & $85 \mathrm{P} / \mathrm{m}^{3}$ & \\
\hline Szczecin & $8.04-23.04$ & $\begin{array}{l}206 \\
16.04\end{array}$ & 8 & 4 & 1119 \\
\hline Drawsko Pomorskie & $10.04-23.04$ & $\begin{array}{l}190 \\
14.04\end{array}$ & 7 & 6 & 1093 \\
\hline Bydgoszcz & $9.04-21.04$ & $\begin{array}{l}264 \\
15.04\end{array}$ & 8 & 6 & 1199 \\
\hline Zielona Gora & $7.04-20.04$ & $\begin{array}{l}412 \\
12.04\end{array}$ & 10 & 9 & 2408 \\
\hline Wroclaw & $8.04-25.04$ & $\begin{array}{l}106 \\
15.04\end{array}$ & 2 & 1 & 519 \\
\hline Opole & $8.04-21.04$ & $\begin{array}{l}331 \\
13.04\end{array}$ & 9 & 8 & 1914 \\
\hline Sosnowiec & $9.04-23.04$ & $\begin{array}{l}364 \\
12.04\end{array}$ & 7 & 6 & 1353 \\
\hline Cracow & $9.04-17.04$ & $\begin{array}{l}829 \\
10.04\end{array}$ & 8 & 8 & 3048 \\
\hline Piotrkow Trybunalski & $10.04-24.04$ & $\begin{array}{l}267 \\
13.04\end{array}$ & 11 & 8 & 1627 \\
\hline Warsaw & $10.04-24.04$ & $\begin{array}{l}357 \\
16.04 \\
\end{array}$ & 9 & 8 & 1853 \\
\hline Lublin & $10.04-23.04$ & $\begin{array}{l}638 \\
13.04 \\
\end{array}$ & 11 & 9 & 3505 \\
\hline Olsztyn & $10.04-24.04$ & $\begin{array}{l}321 \\
17.04 \\
\end{array}$ & 4 & 4 & 1049 \\
\hline Bialystok & $7.04-25.04$ & $\begin{array}{l}109 \\
15.04\end{array}$ & 4 & 1 & 413 \\
\hline
\end{tabular}


Figure 1. Fraxinus pollen count in Szczecin and Drawsko Pomorskie in 2018.

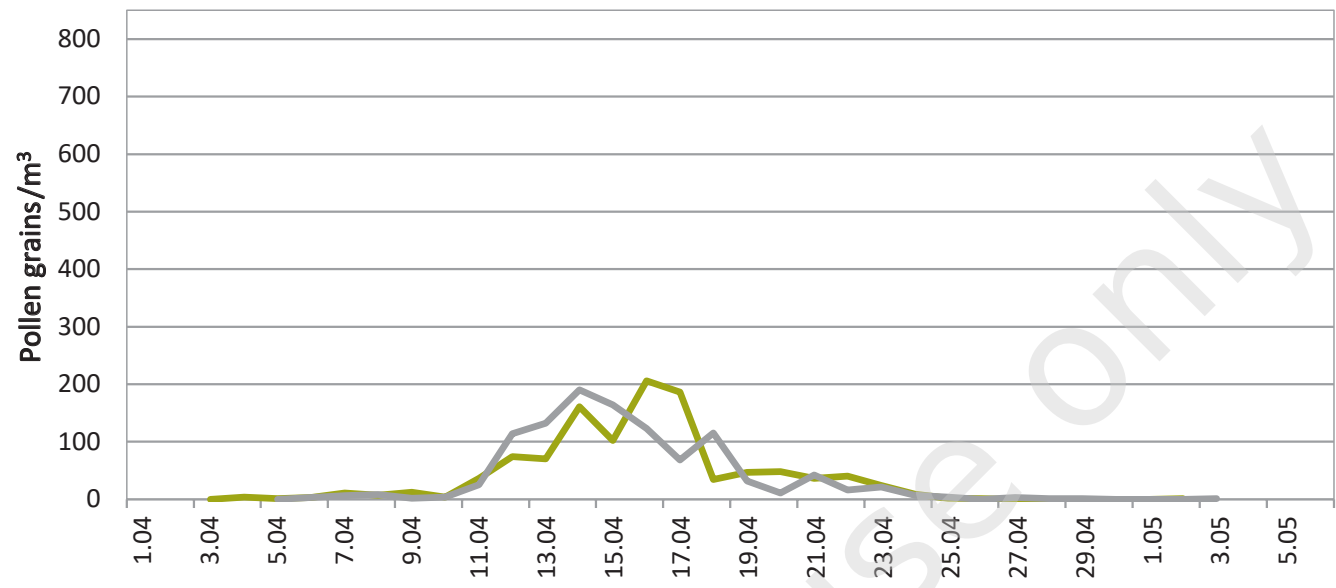

Szczecin Drawsko Pomorskie

Figure 2. Fraxinus pollen count in Opole and Piotrkow Trybunalski in 2018.

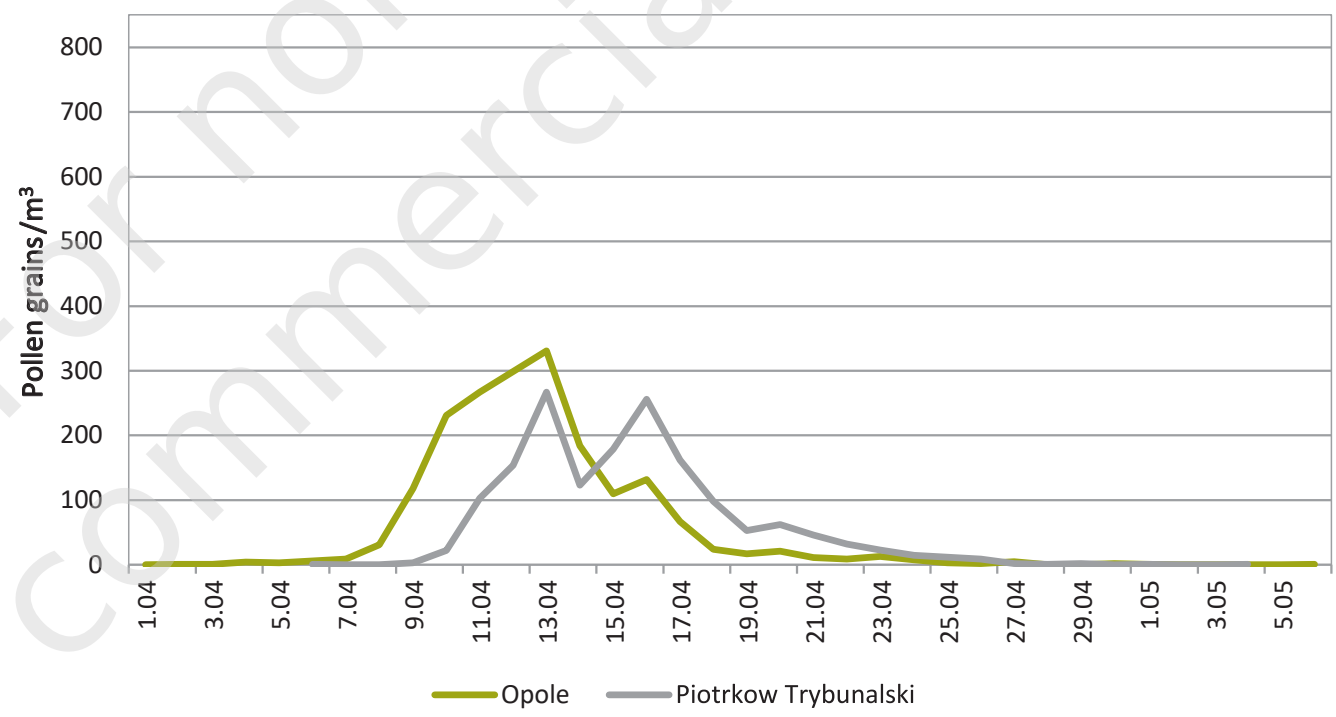

Figure 3. Fraxinus pollen count in Zielona Gora and Lublin in 2018.

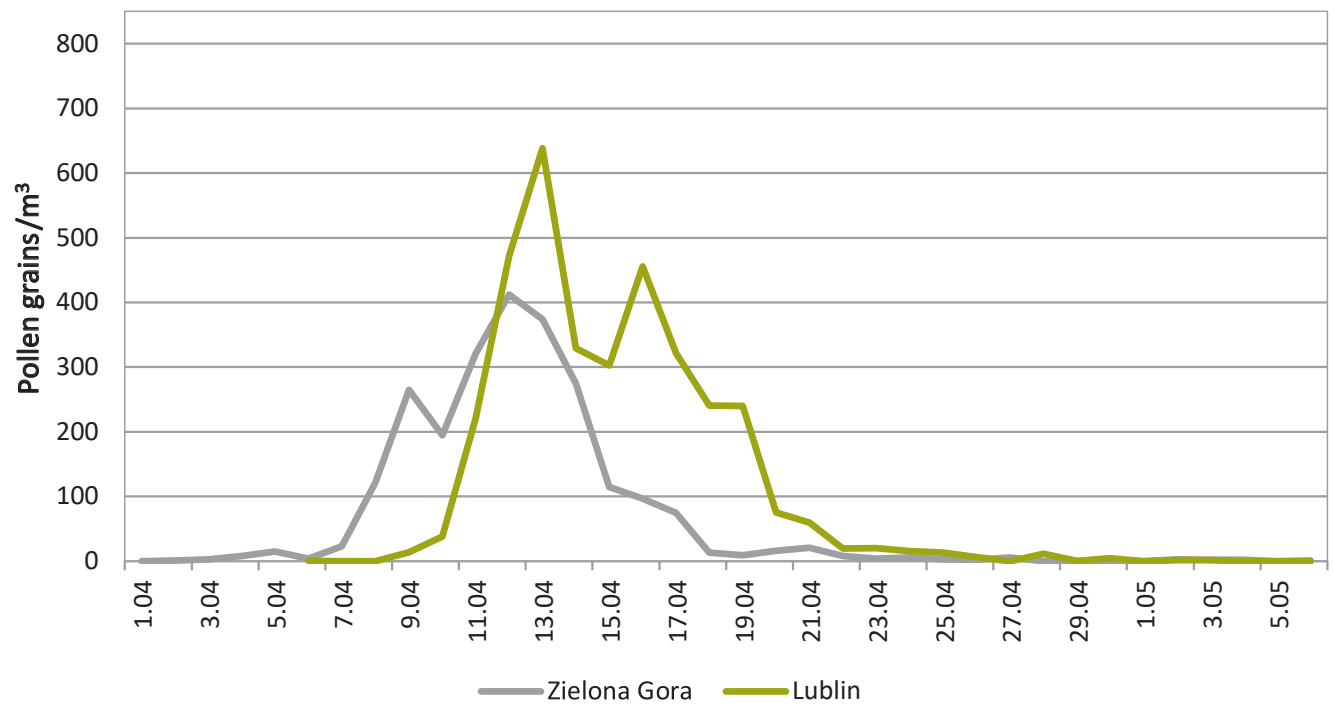


Figure 4. Fraxinus pollen count in Cracow and Sosnowiec in 2018.

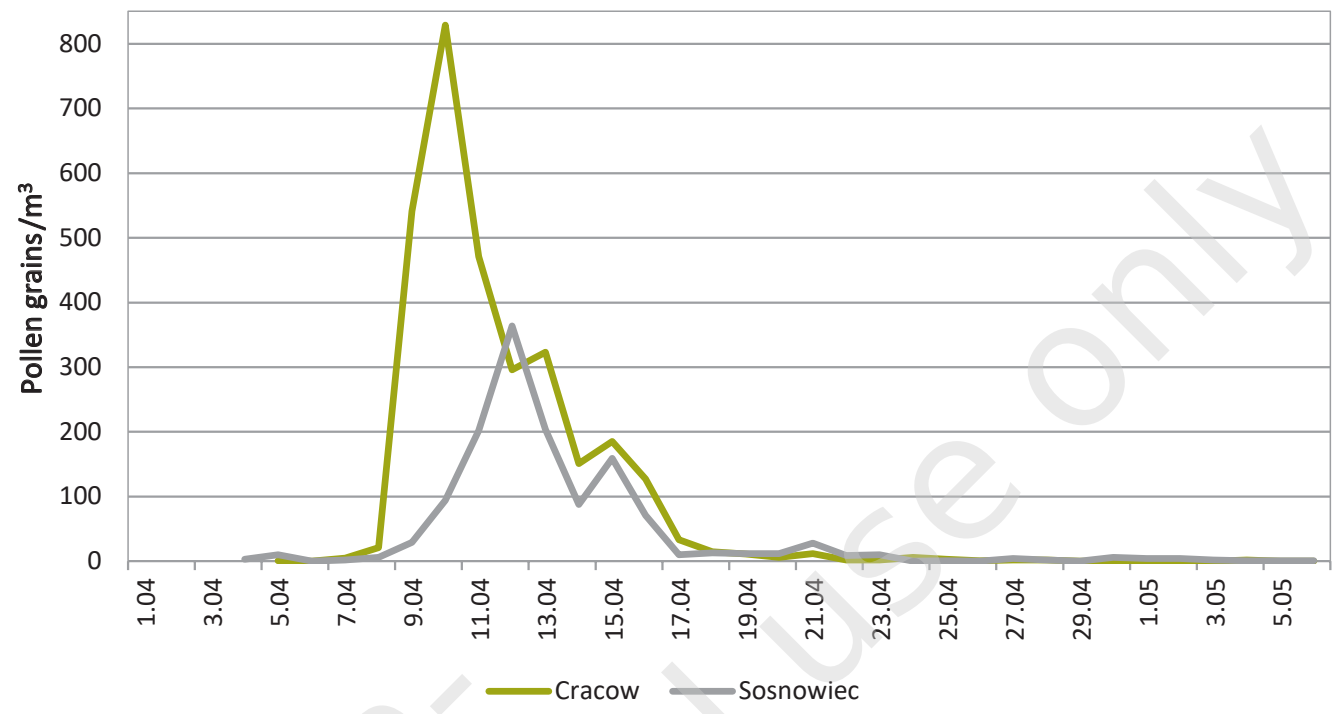

Figure 5. Fraxinus pollen count in Warsaw and Olsztyn in 2018.

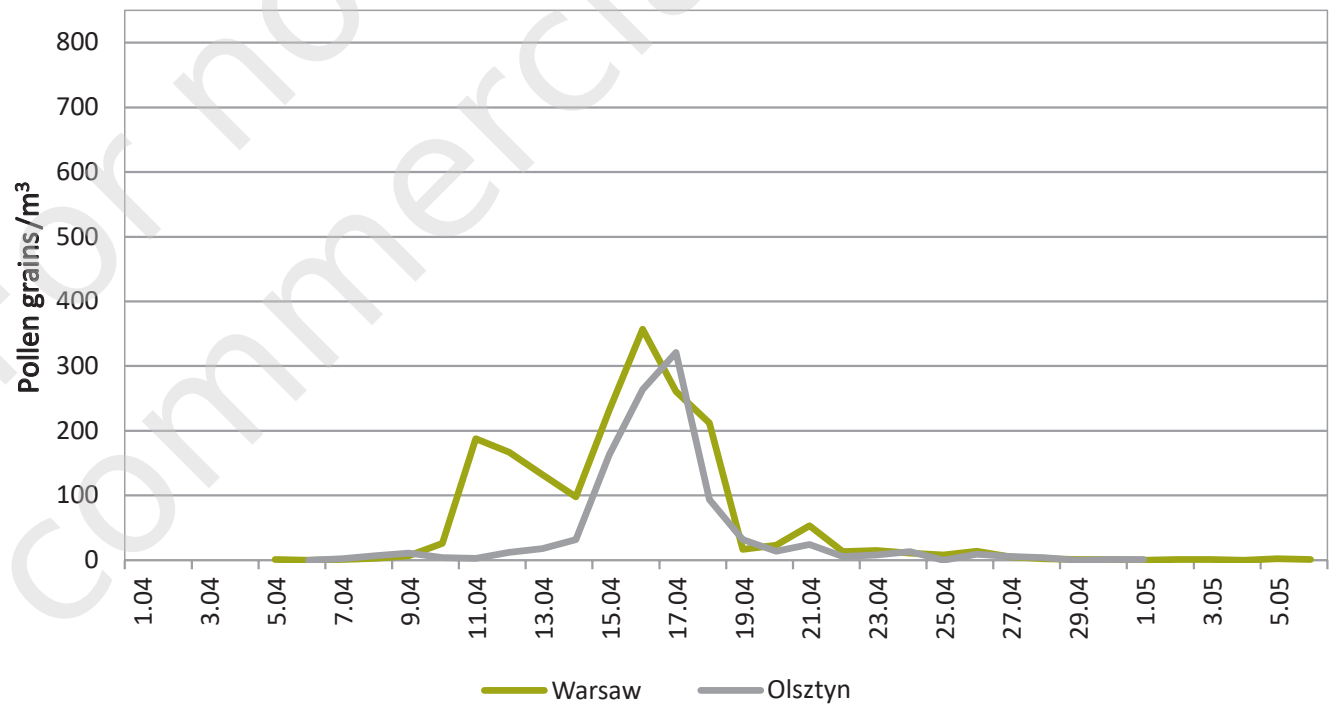

Figure 6. Fraxinus pollen count in Bydgoszcz, Wroclaw and Bialystok in 2018.

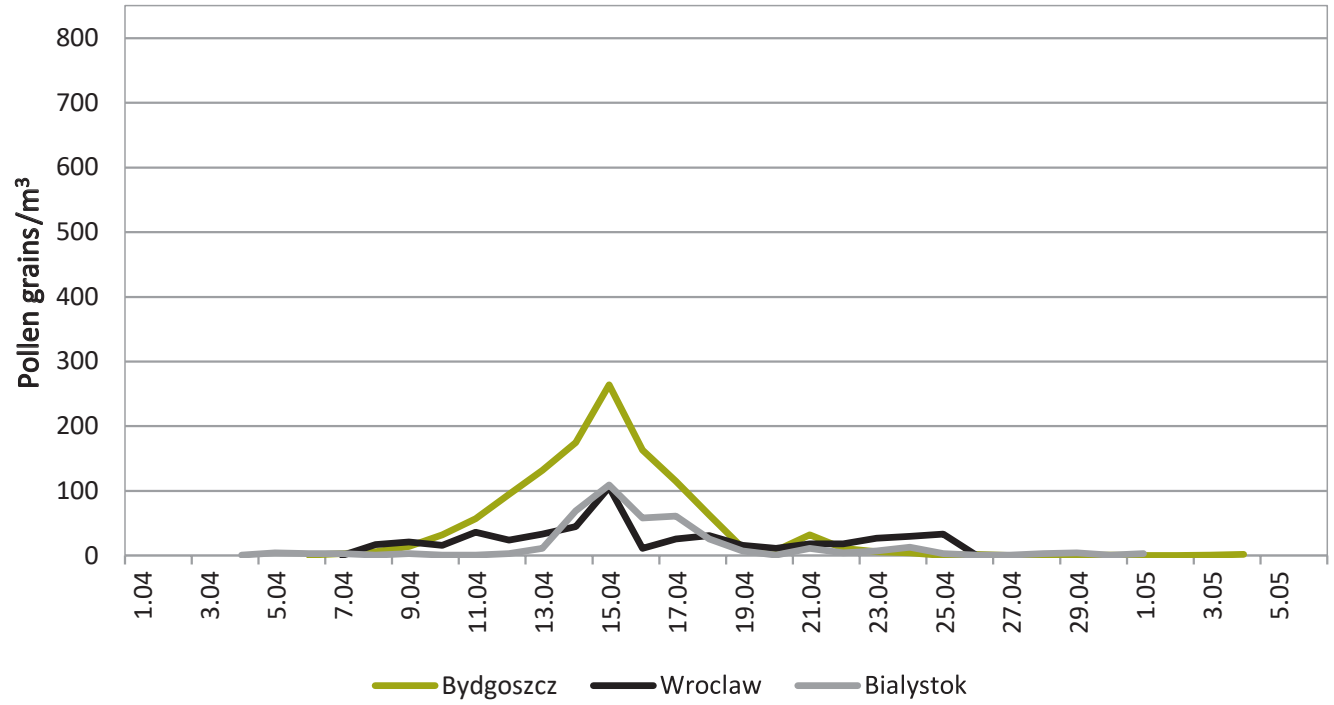


The dates of the seasonal peak in 2018 were similar and occurred between April $10^{\text {th }}$ and April 17 $7^{\text {th }}$; the peak value was recorded earliest in Cracow and latest in Olsztyn. In the previous years, these dates differed significantly between cities. In 2014 the seasonal peak was observed earliest on April $4^{\text {th }}$ (in Zielona Gora) and latest on April 21 $1^{\text {st }}$ (in Bydgoszcz) [10]. In 2017, on the other hand, the highest daily ash pollen concentration occurred between March $31^{\text {st }}$ (in Wroclaw) and April 10 $0^{\text {th }}$ (in Bialystok and Olsztyn) [9].

Similarly to the peak value, the highest total annual pollen count was also recorded in Lublin and Cracow, while the lowest one in Bialystok and Wroclaw (tab. 1). The same trend was found in 2017 [9].

The number of days with a concentration exceeding $45 \mathrm{P} / \mathrm{m}^{3}$ was highest in Lublin and in Piotrkow Trybunalski (11 days), while the lowest one in Wroclaw (2 days). A concentration of $85 \mathrm{P} / \mathrm{m}^{3}$ was exceeded in all the cities - in Lublin and Zielona Gora on 9 days, whereas in Bialystok and Wroclaw on 1 day.

\section{Conclusions}

In most of the cities, the ash pollen season in 2018 started in the first 10 days of April and ended in the third 10 days of this month.

The highest daily ash pollen concentrations were recorded in Lublin and Cracow.

The highest risk of pollen allergy associated with the presence of airborne ash pollen was found in Lublin, Zielona Gora and Piotrkow Trybunalski.

\section{References}

1. Szweykowscy AJ. Stownik botaniczny. Wiedza Powszechna, Warszawa 2003.

2. Scheifinger H, Belmonte J, Buters J et al. Monitoring, modelling and forecasting of the pollen season. In: Sofiev M, Berg- mann KC (eds). Allergenic pollen. Springer Dordrecht Heidelberg New York London 2013: 71-126.

3. Hemmer W, Focke M, Wantke $F$ et al. Ash (Fraxinus excelsior) - pollen allergy in central Europe: Specific role of pollen panallergens and the major allergen of ash pollen, Fra e 1. Allergy 2000, 55: 923-930.

4. Vara A, Fernandez-Gonzalez M, Aira MJ, Rodriguez-Rajo FJ. Oleaceae cross-reactions as potential pollinosis cause in urban areas. Sci Total Environ 2016, 542: 435-440.

5. Guerra F, Galan C, Daza JC et al. Study of sensitivity to the pollen of Fraxinus spp. (Oleaceae) in Cordoba, Spain. J Invest Allergol Clin Immunol 1995, 5(3): 166-170.

6. Wüthrich B. Esche ist nicht Esche. Allergologie 2006, 29(6): 231-235.

7. Rapiejko P. Alergeny pytku roślin. Medical Education, Warszawa 2012

8. Piotrowska-Weryszko K, Weryszko-Chmielewska E. The airborne pollen calendar for Lublin, central-eastern Poland. Ann Agric Environ Med 2014, 21(3): 541-545.

9. Szczygielski K, Puc M, Stacewicz A et al. Ash pollen count in the air of selected Polish cities in 2017. Alergoprofil 2017, 13(2): 85-90.

10. Weryszko-Chmielewska E, Piotrowska-Weryszko K, Rapiejko $P$ et al. Zawartość pytku jesionu w powietrzu wybranych miast Polski w 2014 r. Alergoprofil 2014, 10(3): 36-41.

Authors' contributions: Piotrowska-Weryszko K: 40\%, other Authors: 2,7\% each. Conflict of interests: The authors declare that they have no competing interests.

Financial support: Allergen Research Center, Warsaw, own financial resources of Department of Clinical and Environmental Allergology, Jagiellonian University Medical College and the Ministry of Science and Higher Education in Poland.

Ethics: The contents presented in this paper are compatible with the rules the Declaration of Helsinki, EU directives and standardized requirements for medical journals

Corresponding author:

\section{Krystyna Piotrowska-Weryszko, PhD}

Department of Botany,

University of Life Sciences in Lublin

20-950 Lublin, Akademicka 15 street

e-mail: krystyna.piotrowska@up.lublin.pl 